\title{
Inhibition of cyclooxygenase-2 decreases breast cancer cell motility, invasion and matrix metalloproteinase expression Teri L Larkins ${ }^{1}$, Marchele Nowell ${ }^{2}$, Shailesh Singh ${ }^{1,3}$ and Gary L Sanford*1
}

Address: ${ }^{1}$ Department of Microbiology, Immunology and Biochemistry Morehouse School of Medicine Atlanta, GA 30310-1495, USA, ${ }^{2}$ Georgia State University Atlanta, GA 30302-3965, USA and 3James Graham Brown Cancer Center University of Louisville, School of Medicine Louisville, KY 40202-1756, USA

Email: Teri L Larkins - tlarkins@msm.edu; Marchele Nowell - marchelenowell@aol.com; Shailesh Singh - shailesh.singh@louisville.edu; Gary L Sanford* - gsanford@msm.edu

* Corresponding author

Published: 10 July 2006

BMC Cancer 2006, 6:181 doi:10.1186/147|-2407-6-18|
Received: 14 January 2006

Accepted: 10 July 2006

This article is available from: http://www.biomedcentral.com/I47I-2407/6/18I

(C) 2006 Larkins et al; licensee BioMed Central Ltd.

This is an Open Access article distributed under the terms of the Creative Commons Attribution License (http://creativecommons.org/licenses/by/2.0), which permits unrestricted use, distribution, and reproduction in any medium, provided the original work is properly cited.

\begin{abstract}
Background: Cyclooxygenase (COX) is the rate-limiting enzyme that catalyzes the formation of prostaglandins. The inducible isoform of COX (COX-2) is highly expressed in aggressive metastatic breast cancers and may play a critical role in cancer progression (i.e. growth and metastasis). However, the exact mechanism(s) for COX-2-enhanced metastasis has yet to be clearly defined. It is well established that one of the direct results of COX-2 action is increased prostaglandin production, especially prostaglandin $\mathrm{E}_{2}\left(\mathrm{PGE}_{2}\right)$. Here, we correlate the inhibition of COX-2 activity with decreased breast cancer cell proliferation, migration, invasion and matrix metalloproteinase (MMP) expression.
\end{abstract}

Methods: Breast cancer cells (Hs578T, MDA-MB-23I and MCF-7) were treated with selective COX-2 inhibitors (NS-398 and Niflumic acid, NA). Cell proliferation was measured by staining with erythrosin $B$ and counting the viable cells using a hemacytometer. Cell migration and invasion were measured using migration and invasion chamber systems. MMP expression was determined by enzyme immunoassay (secreted protein) and real-time quantitative polymerase chain reaction (mRNA).

Results: Our results show that there is a decline in proliferation, migration and invasion by the Hs578T and MDA-MB-23I breast cancer cell lines in the presence of either low concentrations (I $\mu \mathrm{M}$ or lower) NA or NS-398. We also report that MMP mRNA and protein expression by Hs578T cells is inhibited by NS-398; there was a $50 \%$ decrease by $100 \mu \mathrm{M}$ NS-398. PGE ${ }_{2}$ completely reversed the inhibitory effect of NS-398 on MMP mRNA expression.

Conclusion: Our data suggests that COX-2-dependent activity is a necessary component for cellular and molecular mechanisms of breast cancer cell motility and invasion. COX-2 activity also modulates the expression of MMPs, which may be a part of the molecular mechanism by which COX-2 promotes cell invasion and migration. The studies suggest that COX-2 assists in determining and defining the metastatic signaling pathways that promote the breast cancer progression to metastasis. 


\section{Background}

Numerous studies indicate that cyclooxygenase-2 (COX2 ) is highly expressed in a variety of human cancers, including colorectal, breast and prostate. In breast cancer, the expression of the COX-2 gene is associated with high tumor grade [1], which suggests it may serve as a prognostic biomarker for the presence of breast cancer. Researchers also found high expression of COX-2 in highly invasive estrogen independent breast cancer cell lines, (MDA-MB-231 (MDA-231) and Hs578T) as well as 12, 0tetradecanoylphorbol-13-acetate (TPA)-induced COX-2 expression, while a poorly invasive and estrogen dependent cell line (MCF-7) did not express COX-2 [2,2,3]. Ristamaki et al. [4] also confirmed that the elevated COX-2 expression seen in $37.4 \%$ of the 1567 invasive breast cancers were associated with a large tumor size, high tumor grade, negative estrogen receptor status, high p53 expression and unfavorable prognosis. Transgenic mice that overexpressed COX-2 in mammary epithelial cells promoted mammary gland tumorigenesis and decreased apoptosis by reducing the expression levels of proapoptotic genes $[4,5]$. When transfecting the breast cancer cell line, MDA-MB-435 with COX-2, the cells migrated significantly better than the untransfected control cells [6]. The expression of COX-2 in breast tumors can be correlated with high metastatic potential.

Many of the critical steps of malignant tumorigenesis, such as cell proliferation, evading apoptosis, stimulating angiogenesis, enhancing cell motility, cell invasiveness and mediating immune suppression, have been associated with cyclooxygenase-2 expression. The end-products of COX-2 activity are prostaglandins and thromboxanes which may mediate these changes in cancer cell progression.

Elevated levels of prostaglandins, notably $\mathrm{PGE}_{2}$, have been detected in breast cancer cell lines, as well as invasive breast cancer $[3,7,8]$. Gilhooly et al. [2] induced COX-2 expression and activity in breast cancer cell lines with TPA which increased the production of $\mathrm{PGE}_{2}$. $\mathrm{PGE}_{2}$ was shown to stimulate cell proliferation indirectly by increasing estrogen levels via the induction of the aromatase gene expression [9]. Other researchers have shown that $\mathrm{PGE}_{2}$, prostacyclin and thromboxanes $\mathrm{A}_{2}$ contribute to tumor angiogenesis by mediating endothelial cell migration through integrin $\alpha \mathrm{V} \beta 3$ and by aiding in the production of angiogenic growth factors $[10,11]$.

Recent data suggest a correlation between COX-2 expression and cell invasiveness. In order for cancer cells to metastasize, the cells must digest and dissolve the extracellular matrix (ECM) and the basement membrane, which requires the secretion and activation of MMPs. The expression and activation of MMPs may be directly proportional to the overexpression of COX-2 in tumor cells. One group has shown that Hs578T breast cancer cells transfected with COX-2 resulted in the activation of MMP-2 [12]. Sivula et al. [13] found increased COX-2 expression in breast cancer specimens, which also exhibited elevated MMP-2 expression and decreased disease specific survival. MMP-2 was elevated in 56 out of 59 invasive breast carcinomas in which expression of COX-2 was moderate to high. Studies also suggest that COX-2 may mediate urokinase plasminogen activator (uPA) production in metastatic breast cancer cell lines that overexpress COX-2. The uPA activates proteases and MMPs that degrade the basement membrane and mediate cytoskeleton reorganization. $[6,12,14]$.

To our knowledge, we are the first to report evidence that COX-2 activity and expression may modulate the expression and activity of several MMPs in COX-2 expressing breast cancer cells. In this study, we screened for eight MMPs in breast cancer cells that were treated with and without of a COX-2 inhibitor. To date, only three groups have reported on studies focused only on the effect of COX-2 activity on the secretion of the gelatinases (MMP2 and -9); all were done on cancers other than breast. Attiga et al. [15] have reported the inhibition of MMP-2 and MMP-9 by COX-2 inhibitors in prostate cancer. Tsuji et al. [16] observed an increase in MMP-2 activation and increase in MMP-14 mRNA expression by Caco- 2 colon cancer cells, which showed high levels of COX-2. MMP-2 levels were decreased in the non-small cell lung cancer cell lines, A549 and H157 when treated with a COX-2 specific inhibitor [17].

The results of a number of epidemiological, clinical and laboratory studies suggest that the administration of COX inhibitors (NSAIDs, aspirin, indomethacin) reduces the incidence of breast, colon and prostate cancers $[15,18$ 23]. Although several researchers have reported on the association of COX-2 overexpression with tumorigenesis in various cancers, many do not address the mechanism by which COX-2 promotes tumorigenesis. Using COX-2 inhibitors to prevent tumorigenesis will allow us to study the properties of COX-2 that influence breast cancer metastasis. The aim of the study reported here was to further elucidate the mechanism in which COX-2 promotes metastasis by using COX-2 selective inhibitors to study the role of COX-2 breast cancer motility and invasion. We were able to demonstrate that low and achievable concentrations of specific COX-2 inhibitors were sufficient to reduce the proliferation, migration and invasion of $\mathrm{COX}$ 2 expressing breast cancer cells. This study also suggests that COX-2 modulates the expression and activity of multiple MMPs involved in breast cancer metastasis. 


\section{Methods}

\section{Cell lines and cell culture}

The Hs578T, MDA-231 and MCF-7 breast cancer cell lines were all obtained from the American Type Culture Collection (Manassas, VA). The Hs578T and MDA-231 are estrogen-independent and highly invasive breast cancer cells. Although there have been studies that have looked at the expression of COX-2 in these breast cancer cell lines $[2,3,24]$, we wanted to be certain that under our experimental conditions we saw similar results. We found high expression of COX-2 by both cell lines (Fig. 1). The MCF7 cell line is an estrogen-dependent and poorly invasive
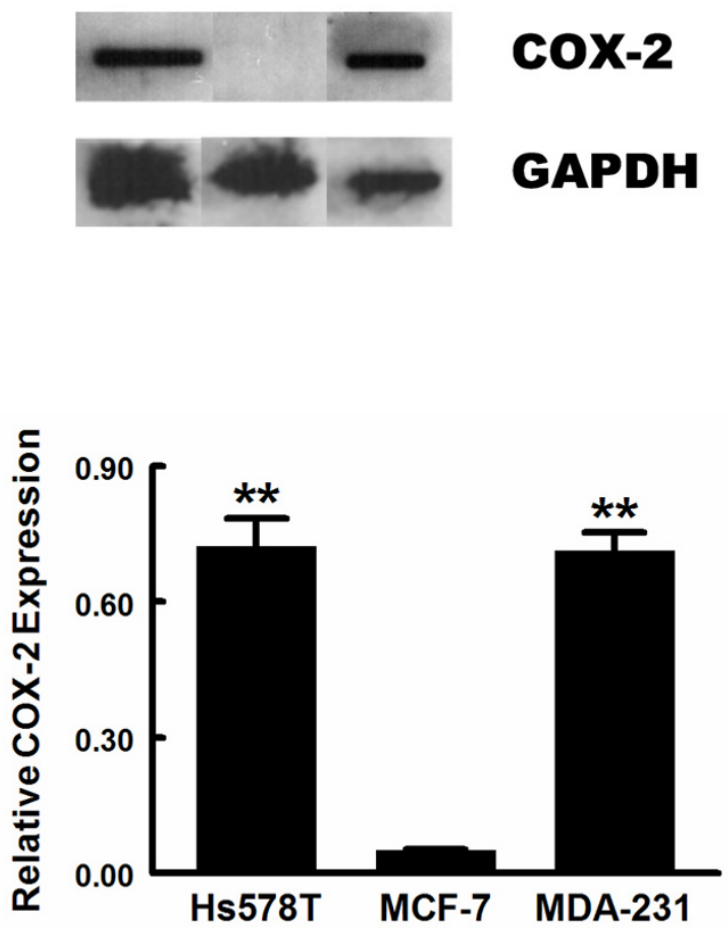

\section{Figure I}

Expression of COX-2 protein in different breast cancer cell lines. (Hs578T, MCF-7 and MDA-23 I). Protein was extracted with RIPA buffer and the expression of COX-2 protein detected by immunoblotting and then quantitated by densitometry. Quantitated data were normalized to GAPDH. The relative units (RU) and ratio for the COX-2 and GAPDH bands for the different breast cancer cell lines were as follows: Hs578T (COX-2-57878/GAPDH-80I82) = 0.72I8, MCF7 (COX-2-587I/GAPDH-74734) = 0.05, MDA-23 I (COX-2$4386 I / G A P D H-6 I 470)=0.7135$. Data for invasive cells lines were compared to poorly invasive cell line by one-way ANOVA followed by Student-Newman-Keuls test (,**p < $0.01)$. breast cancer cell line that did not express COX-2. All cell lines were adapted for growth in Dulbecco's modified Eagle's medium (DMEM, Cambrex-Biowhittaker Walkersville, MD) supplemented with $0.1 \mathrm{Unit} / \mathrm{ml}$ bovine insulin (Sigma Chemical Co. St. Louis, MO), 100 I. U. penicillin, $100 \mu \mathrm{g} / \mathrm{ml}$ streptomyocin, $0.25 \mu \mathrm{g} / \mathrm{ml}$ amphotericin B (Cellgro Herndon, VA) and 10\% fetal bovine serum (FBS Hyclone, Logan UT). When cells reached confluency, the cells were harvested by trypsinizing with $0.25 \%$ trypsin, $2.21 \mathrm{mM}$ EDTA-Na in Hank's Balanced Salt solution w/ $\mathrm{Ca}^{2+}, \mathrm{Mg}^{2+}$ and $\mathrm{NaHCO}_{3}$ (Cellgro Herndon, VA), pelleted, resuspended in fresh medium and seeded in multiple 75$\mathrm{cm}^{2}$ flasks (Corning Corning, NY).

\section{Cell proliferation and viability}

The Hs578T $\left(1.5 \times 10^{5}\right)$, MDA-231 $\left(1 \times 10^{4}\right)$ and MCF-7 cells $\left(1.5 \times 10^{5}\right)$ were seeded on Falcon Multiwell ${ }^{\mathrm{TM}} 6$-or 12-well plates (Becton Dickinson-BD Biosciences Discovery Labware Franklin Lakes, NJ) and grown for 48-72 h. The plates were washed with serum-free DMEM once and then incubated for $1 \mathrm{~h}$ in DMEM with $2 \%$ FBS. Control cells were treated with the vehicle only. Experimental cells were incubated with $0.1,1.0$ and $10 \mu \mathrm{M}$ NS-398 (N-(2cyclohexyloxy-4-nitrophenyl)-methanesulfonamide) or $10 \mu \mathrm{M}$ niflumic acid (NA) for $24 \mathrm{~h}$ at $37^{\circ} \mathrm{C}$ in $5 \% \mathrm{CO}_{2}$, harvested and homogeneous cell suspension prepared and counted. The number of viable cells was determined by the dye exclusion method using erythrosin B and measured by hemacytometer counting.

\section{Migration assay}

Cell migration assays were performed using a modification of the protocol described by Attiga et al [15]. The BD Falcon Cell Culture Insert System containing PET (polyethylene terephthalate) membranes with $8 \mu \mathrm{m}$ pores (BD Biosciences Discovery Labware Franklin Lakes, NJ) was utilized in the assay. The Hs578T and MDA-231 cells were harvested and resuspended into serum-free medium containing NS-398 $(0.1,1.0$ and $10 \mu \mathrm{M})$ or the vehicle. The upper chamber of the insert was filled with $500 \mu$ l of the cell and drug suspension $\left(1 \times 10^{5}\right.$ cells $)$ and $1.5 \mathrm{ml}$ of (NIH/3T3) fibroblast-conditioned medium (FCM) was added to the lower chamber. FCM served as the chemoattractant. The conditioned medium was collected from NIH 3 T3 cells grown in serum-free DMEM after $24 \mathrm{~h}$. The plate was incubated in a humidified environment at $37^{\circ} \mathrm{C}$ with $5 \% \mathrm{CO}_{2}$ for $24 \mathrm{~h}$. After incubation, the cells were removed from upper surface of the membrane by wiping with a moist cotton swab. The lower surface of the membrane (cells that migrated) was stained for $10 \mathrm{~min}$ with $0.5 \%$ crystal violet in $25 \%$ methanol, rinsed with distilled water to remove excess stain not absorbed by cells and airdried overnight. Digital images of the stained cells were obtained prior to the extraction of dye. The crystal violet was then extracted with $900 \mu \mathrm{l}$ of $0.1 \mathrm{M}$ sodium citrate in 
$50 \%$ ethanol. The absorbance was measured at $585 \mathrm{~nm}$ (using Genova Life Science Analyser (Jenway Felsted, England) spectrophotometer).

\section{Wound migration assay}

The Hs578T and MDA-231 cells $\left(2.0 \times 10^{5}\right)$ were seeded into six-well plates and grown to $100 \%$ confluency. The confluent cells were carefully wounded with sterile polished pasteur pipet tips and any cellular debris was removed by washing with $\mathrm{PBS}$. The wounded monolayers were then incubated in the presence of NA (1.0 and 100 $\mu \mathrm{M})$ for 0,5 and $24 \mathrm{~h}$ time periods and digitally photographed. The distance between the wound edges was measured using Adobe Photoshop 6.0.

\section{Invasion assay}

Cell invasion of the breast cancer cells were assessed by using the BD BioCoat ${ }^{\mathrm{TM}}$ FluoroBlok $^{\mathrm{TM}}$ Invasion System (BD Biosciences Franklin, NJ) and procedures were followed according to the manufacturer. Monolayer cells grown to $80 \%$ confluency and labeled in situ with $10 \mu \mathrm{g} / \mathrm{ml}$ of $1,1^{\prime}$ didodecyl-3,3,3',3'-tetramethylindocarbocyanine perchlorate $\left(\operatorname{DiIC}_{12}(3)\right)$ DiI fluorophore lipophilic tracer (Molecular Probe, Invitrogen Carlsbad, CA) in medium for $1 \mathrm{~h}$ at $37^{\circ} \mathrm{C}$. The FluoroBlok Invasion insert plate was rehydrated with warm PBS for $2 \mathrm{~h}$ at $37^{\circ} \mathrm{C}$. Cells were harvested and resuspended in serum-free DMEM containing NS-398 $(0.1,1.0$ and $10 \mu \mathrm{M})$ or the vehicle. NIH/3T3 fibroblast-conditioned medium (FCM) $750 \mu \mathrm{l}$ was added to the lower chamber and the cell suspension $(500 \mu \mathrm{l})$ was added to the upper chamber. The system was incubated $22-24 \mathrm{~h}$ at $37^{\circ} \mathrm{C}$ and the fluorescence of the cells that invaded was read directly with a GENios Pro fluorescence plate reader (Tecan, San Jose, CA) at excitation/emission wavelengths of 535/590 $\mathrm{nm}$.

\section{RNA isolation and real-time PCR}

Total RNA was extracted from the Hs578T cells treated with NS-398 and/or PGE 2 (control cells received the vehicle only), using the RNeasy mini Kit (Qiagen Valencia, $\mathrm{CA})$ according to the manufacturer's instructions. The RNA was eluted and resuspended in RNA secure (Ambion San Diego, CA). The concentration and purity of the RNA was determined by measuring the absorbance at $260 \mathrm{~nm}$ $\left(\mathrm{A}_{260}\right)$ and determining the ratio of the readings at $260 \mathrm{~nm}$ and $280 \mathrm{~nm}\left(\mathrm{~A}_{260} / \mathrm{A}_{280}\right)$. Complimentary DNA (cDNA) was prepared from $2 \mu \mathrm{g}$ of RNA using Omniscript Reverse Transcriptase (Qiagen Valencia, CA), $2.5 \mu \mathrm{M}$ random primers (Invitrogen Carlsbad, CA) and $0.5 \mathrm{U} / \mu \mathrm{l}$ RNase Inhibitor (Ambion Austin, TX) and incubated at $37^{\circ} \mathrm{C}$ for $1 \mathrm{~h}$.

The cDNA generated from the reverse transcriptase reaction was amplified by real-time PCR using specific MMP$(1,2,3,9,10,11,13,14)$ and $18 S$ primers and the SYBR
Green polymerase chain reaction master mix reagents. The $18 \mathrm{~S}$ rRNA was used a as a standard. We performed the PCR reaction according to the previously published methods in Singh et al [25]. The master mix for each cDNA sample was composed of $5 \mu \mathrm{l}$ of the diluted cDNA $(20 \mu \mathrm{l}$ cDNA $+80 \mu \mathrm{l}$ of nuclease-free water Ambion Austin, TX), $15 \mu \mathrm{H}_{2} \mathrm{O}, 5 \mu \mathrm{l} 10 \mathrm{ng} / \mathrm{ml}$ reverse and forward primers, and the $25 \mu \mathrm{l} \mathrm{Q}{ }^{\mathrm{TM}} \mathrm{SyBr}$ Green Supermix (Bio-Rad Hercules, $\mathrm{CA})$. The reaction was performed according to the following program: $10 \mathrm{~min}$ at $95^{\circ} \mathrm{C}$ for activating the polymerase, the 40 cycles of $15 \mathrm{~s}$ at denaturation temperature of $95^{\circ} \mathrm{C}, 1 \mathrm{~min}$ of annealing at $60^{\circ} \mathrm{C}$ and the reaction was held at $4{ }^{\circ} \mathrm{C}$. The relative MMP mRNA expression to the $18 \mathrm{~S}$ rRNA copies was quantified by real-time PCR analysis using the Bio-Rad Icycler and software (Bio-Rad Hercules, CA).

\section{Pro and active metalloproteinase protein detection}

Cells $\left(1 \times 10^{5}\right)$ were seeded in 12 -well plates and grown to $70-80 \%$ confluency. The plates were washed with serumfree DMEM once and then incubated for $1 \mathrm{~h}$ in $1 \mathrm{ml}$ of DMEM with 2\% FBS and either NS-398 or the vehicle. The pro and active gelatinases (MMP-2 and MMP-9), collagenases (MMP-1 and MMP-13), and stromelysins (MMP3 and MMP-10) levels released in the media were measured using a Quantikine colorimetric and Fluorokine fluorometric enzyme immunoassay (EIA) kit (R\&D Systems Minneapolis, MN) using the manufacturer's instructions. After $24 \mathrm{~h}$, the media were collected in microcentrifuge tubes and centrifuged for $10 \mathrm{~min}$ at $10,000 \mathrm{~g}$ in order to remove particulates. The samples were stored frozen at $-80^{\circ} \mathrm{C}$ prior to the assay. The samples and MMP standards were incubated on a pre-coated polyclonal or monoclonal MMP antibody 96 well-plate for $2 \mathrm{~h}$ on a shaker at room temperature. The intensity of color on the Quantikine EIA plates was determined by Spectra Max 190 and SOFTmax-Pro 4.3 Life Sciences Ed. (Molecular Devices Sunnyvale, CA) at a wavelength of $450 \mathrm{~nm}$ with a correction of $540 \mathrm{~nm}$. The fluorescent signal in the sample on the Fluorokine EIA wells was determined by the GENios Pro fluorescence plate reader (Tecan, San Jose, CA) at excitation/emission wavelengths of $340 \mathrm{~nm} / 465 \mathrm{~nm}$.

\section{Statistical analysis}

Statistical significance was determined by one-way ANOVA with Student-Newman-Keuls post test was performed using GraphPad InStat v3.00. The data was expressed as the mean \pm S.E.; significance was achieved at $\mathrm{p}$ values $<0.05$.

\section{Results}

Growth inhibition of COX-2 expressing breast cancer cells We treated the Hs578T, MDA-231 and MCF- 7 breast cancer cells with NS-398 and NA for $24 \mathrm{~h}$ and examined the 
effects of the cell proliferation. Treatment of the two COX2 expressing cell lines, Hs578T and MDA-231 with 0.1, $1.0,10 \mu \mathrm{M}$ NS-398 and NA impeded the growth of the cells. NS-398 resulted in a 30\% growth inhibition of Hs578T cells $(\mathrm{p}<0.01)$ and $40 \%$ growth inhibition of MDA-23l cells ( $\mathrm{p}<0.05)$ at $0.1 \mu \mathrm{M}$ (Fig. 2). We also found a 37\% inhibition ( $\mathrm{p}<0.05$ ) of MDA-231 growth by 10 $\mu \mathrm{M}$ NA compared to the control (Fig. 2b). The MCF-7 cells did not show a difference in growth when treated with NS398 (data not shown). The COX-2 inhibitors did not significantly affect the cell viability. There was $85 \%$, or higher, cell viability seen after treatment with COX-2 inhibitors, up to $10 \mu \mathrm{M}$ indicated no cytotoxicity.

\section{A}

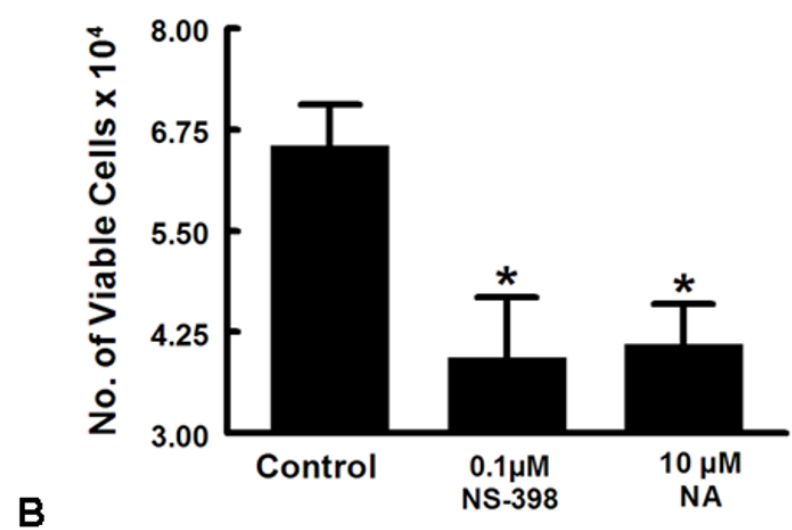

B

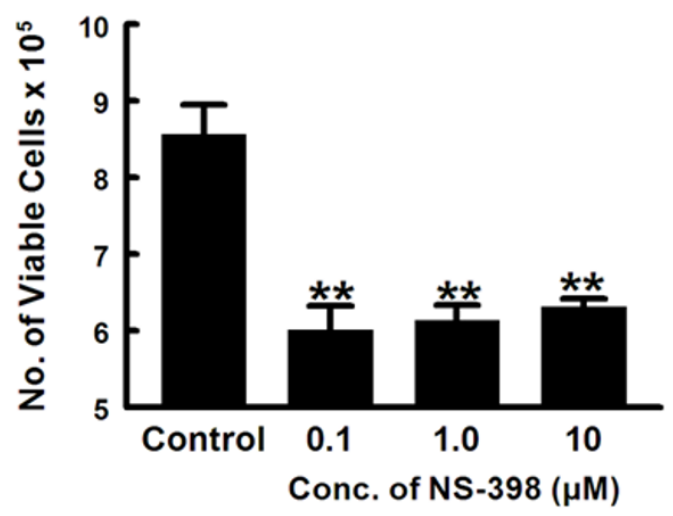

Figure 2

Effect of COX-2 inhibitors on breast cancer cell proliferation. A) I $\times 10^{4}$ MDA-23 I cells and B) $1.5 \times 10^{5} \mathrm{Hs} 578 \mathrm{~T}$ were seeded, grown for $48 \mathrm{~h}$ and then treated with COX-2 inhibitors (NS-398 and Niflumic Acid) or the vehicle for $24 \mathrm{~h}$. Cells were harvested and counted as described in the Methods. Data for treated cells were compared to untreated controls by one-way ANOVA followed by Student-NewmanKeuls test $\left(* p<0.05,{ }^{*} p<0.01\right)$.

\section{Inhibition of cell migration and invasion with a COX-2 inhibitor}

We evaluated the effect of the COX-2 inhibitors on the cell motility and invasiveness of MDA-231 and Hs578T breast cancer cells. Cell motility and invasion are a measure of metastatic potential cancer cells. Treatment with $1.0 \mu \mathrm{M}$ NS-398 inhibited MDA-231 cell motility by 35\% (p < 0.05) (Fig. 3a). Confluent MDA-231 cells subjected to the scratch wound assay in the presence of 1.0 and $100 \mu \mathrm{M}$ NA showed a significant delay in cells moving into the injury area. The control cells migrated into the wound area by $5 \mathrm{~h}$ to such an extent that the wound edges were indistinguishable, whereas the experimental group of cells did not migrate into and completely close the wound area until 24 h (Fig. 3b).

Figure 4a shows that the motility of Hs578T cells was significantly decreased by $21 \%$ (p < 0.05 ) by $10 \mu \mathrm{M}$ NS-398 when compared to the control. Inhibition of Hs578T cell motility by COX-2 inhibitors was also confirmed by the scratch wound assay. Figure $4 \mathrm{~b}$ shows that Hs578T wound incubation with 1 and $100 \mu \mathrm{M}$ NA resulted in a significant delay in cell migration compared to the control (Fig. 4b).

Prior to the migration phase of metastasis, breast cancer cells must invade the basement membrane and the extracellular matrix. We measured the invasive ability of breast cancer cells on Matrigel coated membranes. Invasion of MDA-231 cells was inhibited by $11 \%$ in response to 10 $\mu \mathrm{M}$ NS-398 ( $\mathrm{p}<0.01$ ) (Fig. 5a). We found a $21 \%$ decrease of the invasion of Hs578T cells by $10 \mu \mathrm{M}$ NS-398 (Fig. $5 b)$.

\section{Effect of COX-2 inhibition on the secretion of MMPs}

We assessed the dose-dependent effects of NS-398 on MMP secretion by Hs578T and MDA-231 cells. After $24 \mathrm{~h}$, there was a $67 \%$ decrease in MMP-1, 45\% in MMP-2 and $65 \%$ in MMP-3 secretion by Hs578T cells treated with 100 $\mu \mathrm{M}$ NS-398 (Fig. 6). We also observed a significant reduction $(66 \%)$ of MMP-13 when the cells were treated with $50 \mu \mathrm{M}$ NS-398 (Fig. 6d). In contrast, MMP-9 and MMP-10 were undetectable in the media of Hs578T cells, suggesting that the cells did not secrete these MMPs.

Out of the six MMPs assessed by EIA, we were only able to detect the presence of MMP-1 and MMP-9 in the media of MDA-231 cells. There was about a 20\% decrease for both MMP-1 and MMP-9 secreted by these cells treated with 50 $\mu \mathrm{M}$ NS-398 (Fig. 7). We found a 15\% reduction in active MMP-2 and 20-30\% reduction in active MMP-9 by immunoblotting analysis for MDA-231 cells treated with the NA or NS-398, respectively (data not shown). 


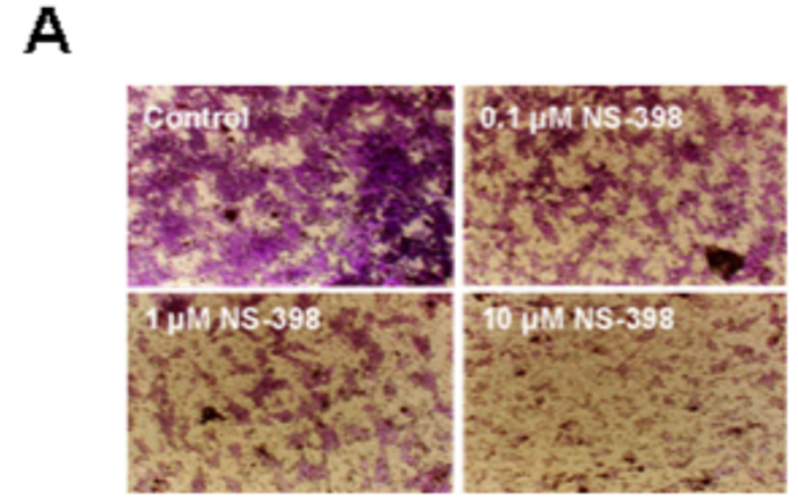

B

Niflumic Acid

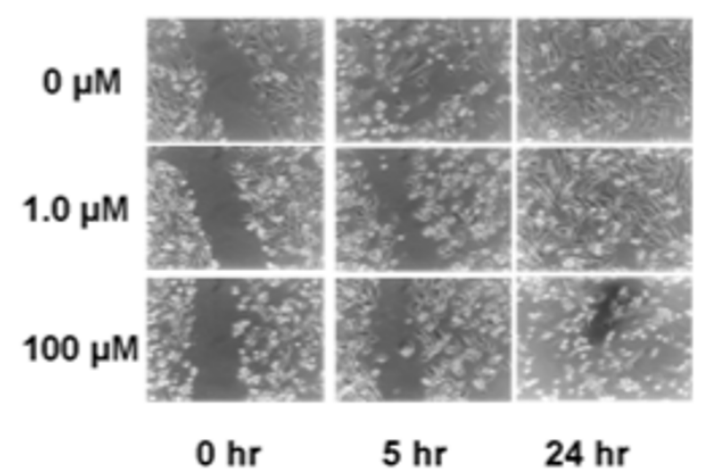

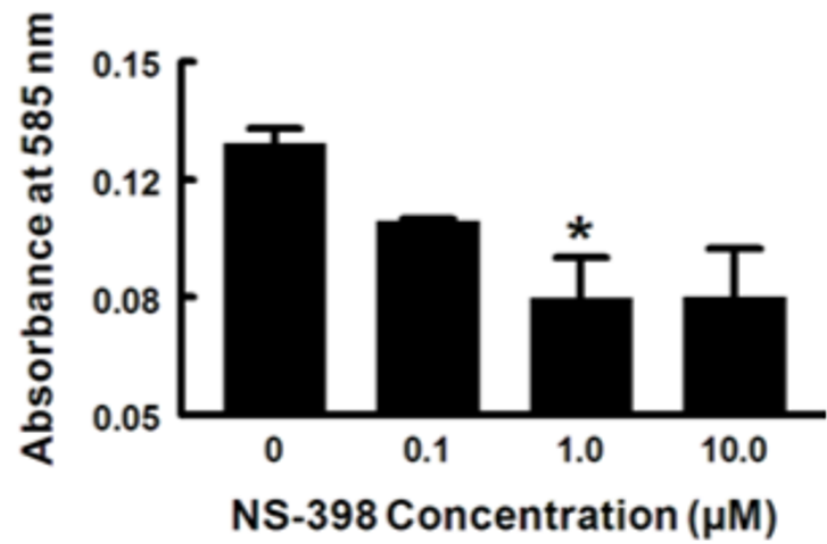

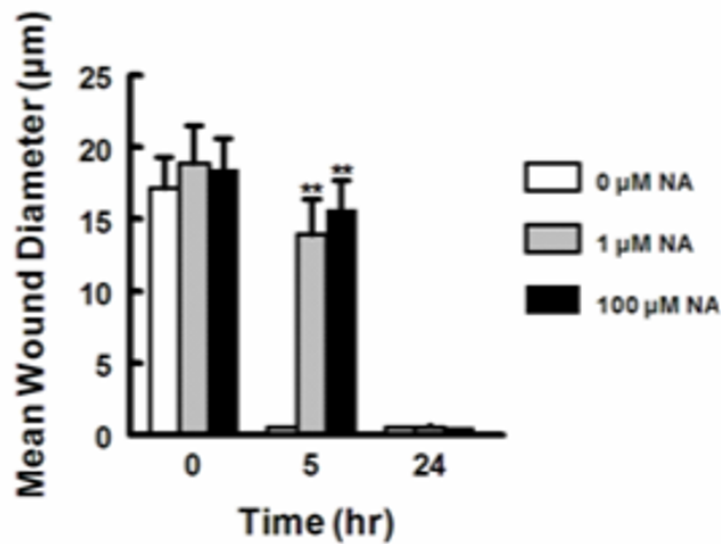

\section{Figure 3}

The effect of COX-2 inhibition on the migration of MDA-23 I cells. A) Cells $\left(1 \times 10^{5}\right)$ were placed in the upper chamber inserts with or without NS-398 in serum-free DMEM and allowed to migrate for $24 \mathrm{~h}$. FCM was used as a chemoattractant to stimulate the migration of the cells. B) Wound migration assay. Confluent MDA-23I cells cultured in six well dishes were wounded with a sterile pipette tip and then incubated with or without Niflumic Acid for $24 \mathrm{~h}$. Photographs were taken with a phase contrast microscope and measurements with Adobe photoshop 6.0. Values were significant $\left(*_{p}^{*}<0.05\right.$, **p $\left.<0.01\right)$ when compared to untreated controls (0 $\mu$ M NA or NS-398).

\section{MMP mRNA expression in Hs578T in the presence of COX-2 inhibitor}

Table 1 shows detectable basal levels of MMPs (1, 2, 3, 9, $10,11,13$ and 14) in the COX-2 expressing cell line, Hs578T before treatment with NS-398 with or without $\mathrm{PGE}_{2}$. MMP-2 and -3 exhibited the highest number of transcripts produced by the cells compared to the other MMPs at basal levels which corresponds with the trend of the active protein secreted by the Hs578T. The MMPs that displayed barely detectable transcripts at basal levels were MMP-10 and -14. This is consistent with EIA results, when active MMP-10 was not detected in the media. We observed a significant 2 log-fold and 4 log-fold decline in MMP-2 and MMP-3 expression levels when the cells were treated with $10 \mu \mathrm{M}$ NS-398. MMP 1, 9, 11 and 14 were either below detection limits or at barely detectable levels when the Hs578T cells were treated with 10 and $100 \mu \mathrm{M}$ NS-398. One of the products of COX-2 is $\mathrm{PGE}_{2}$; this prostaglandin reversed the inhibitory effect of NS-398 on the MMP mRNA expression. In some cases $\mathrm{PGE}_{2}$ actually resulted in MMP levels that were greater than control levels. These data suggests that NS-398 reduced MMP mRNA expression and that $\mathrm{PGE}_{2}$ may promote the invasion of breast cancer cells through enhancing MMP secretion.

\section{Discussion}

Prognosis of breast cancer patients is strongly correlated with the stage of the cancer at the initial diagnosis. If the 
Table I: Effect of COX-2 Inhibitor and PGE ${ }_{2}$ on MMP mRNA Expression. Expression of MMP mRNA in Hs578T cells in the presence of

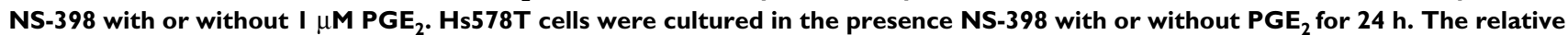
quantitation of the gene expression of the MMP mRNA was calculated against an I8S rRNA standard. The number of copies of MMP mRNA per $10^{6}$ copies of 185 rRNA was determined by real time-PCR according to the methods of Singh et al [25]. The real-time PCR analysis was capable of detecting $>5$ copies of $m R N A$. Hence, copy numbers $<5$ were below detection (BD) limits. Significance $(n=4$, *p $<0.05$ ) was determined by comparing the treated Hs578T cells to the untreated control. \#The data in this column has an $n=2$ and is listed to show the direction of the effect of $\mathrm{PGE}_{2}$.

\begin{tabular}{|c|c|c|c|c|c|}
\hline \multirow[t]{2}{*}{ Type of MMP } & \multicolumn{4}{|c|}{ NS-398 $(\mu \mathrm{M})$} & \multirow{2}{*}{$\begin{array}{c}\text { NS-398/PGE }{ }_{2}(\mu M) \# \\
1.0 / 1.0\end{array}$} \\
\hline & Control & I & 10 & 100 & \\
\hline MMP-I & $1.04 \times 10^{2}$ & $\mathrm{BD}$ & $\mathrm{BD}$ & $\mathrm{BD}$ & $3.58 \times 10^{3}$ \\
\hline MMP-2 & $2.09 \times 10^{5}$ & $3.93 \times 10^{3 *}$ & $3.87 \times 10^{2 *}$ & $1.06 \times 10^{3 *}$ & $3.11 \times 10^{7}$ \\
\hline MMP-3 & $3.42 \times 10^{5}$ & $5.73 \times 102 *$ & $28.0^{*}$ & $1.08 \times 102 *$ & $3.26 \times 10^{13}$ \\
\hline MMP-9 & 16.4 & $\mathrm{BD}$ & $\mathrm{BD}$ & $\mathrm{BD}$ & $1.06 \times 10^{5}$ \\
\hline MMP-IO & $\mathrm{BD}$ & $\mathrm{BD}$ & $\mathrm{BD}$ & $\mathrm{BD}$ & 38.4 \\
\hline MMP-I I & $8.31 \times 10^{3}$ & 6.92 & $\mathrm{BD}$ & $\mathrm{BD}$ & $1.85 \times 10^{9}$ \\
\hline MMP-I3 & $3.93 \times 10^{2}$ & 57.9 & 11.7 & 4.83 & $1.70 \times 10^{6}$ \\
\hline MMP-I4 & $\mathrm{BD}$ & $\mathrm{BD}$ & $\mathrm{BD}$ & $\mathrm{BD}$ & $4.53 \times 10^{4}$ \\
\hline
\end{tabular}

A
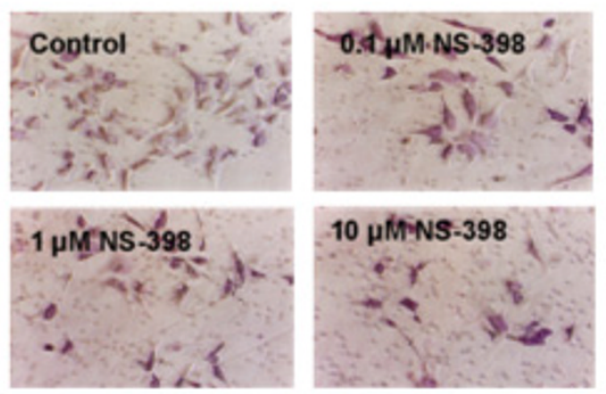

B

Niflumic Acid

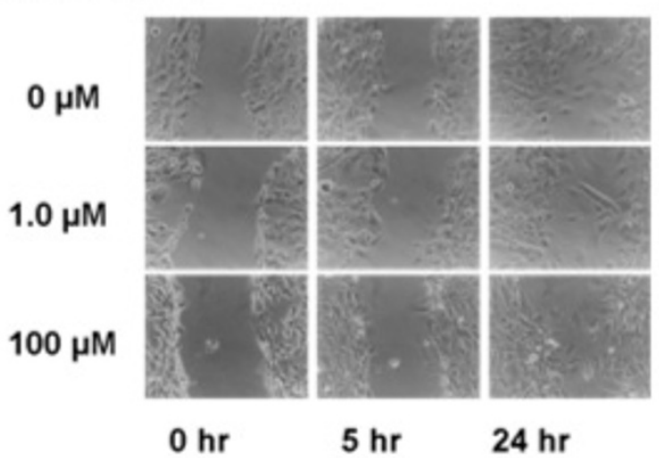

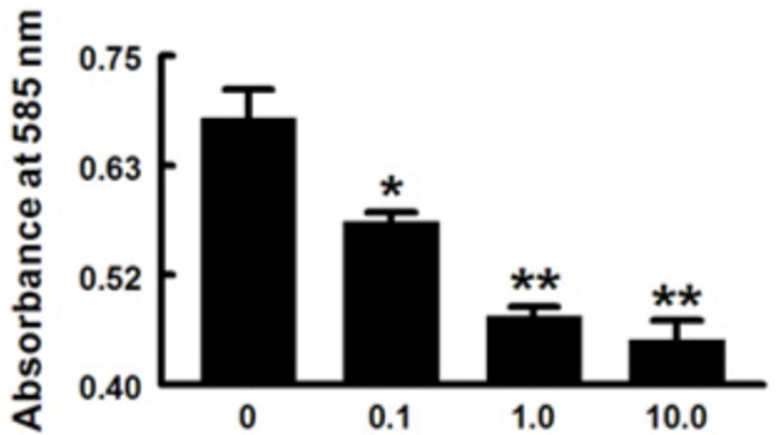

NS-398 Concentration ( $\mu \mathrm{M})$

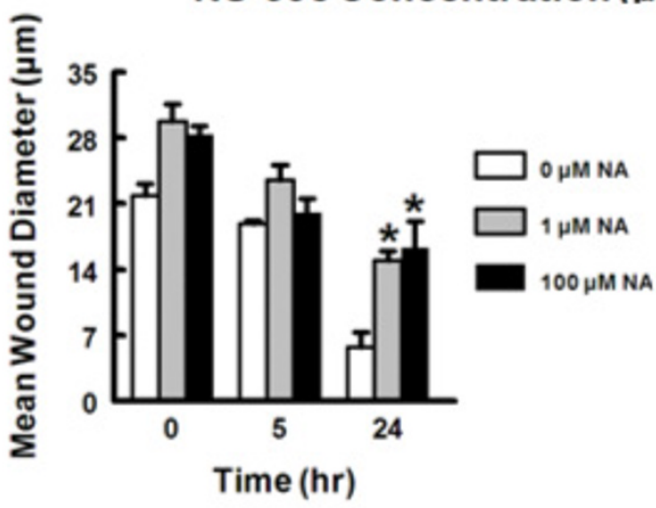

Figure 4

The effect of COX-2 inhibition on migration of Hs578T cells. A) Cells $\left(I \times 10^{5}\right)$ were placed in the upper chamber inserts with or without NS-398 in serum-free DMEM and allowed to migrate for $24 \mathrm{~h}$. FCM was used as a chemoattractant to stimulate the migration of the cells. B) Wound migration assay. Confluent Hs578T cells cultured in six well dishes were wounded with a sterile pipette tip and then incubated with or without Niflumic Acid for $24 \mathrm{~h}$. Photographs were taken with a phase contrast microscope and measurements with Adobe photoshop 6.0. Values were significant $\left(*^{*}<0.05\right)$ when compared to untreated controls (0 $\mu$ M NA or NS-398). 
A

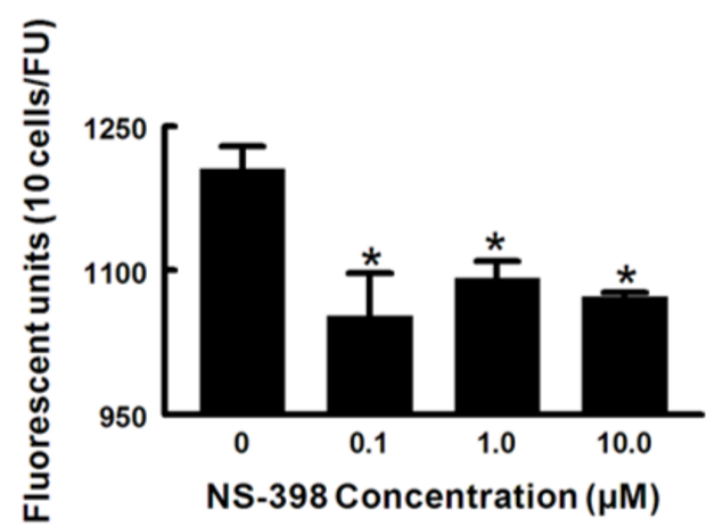

B

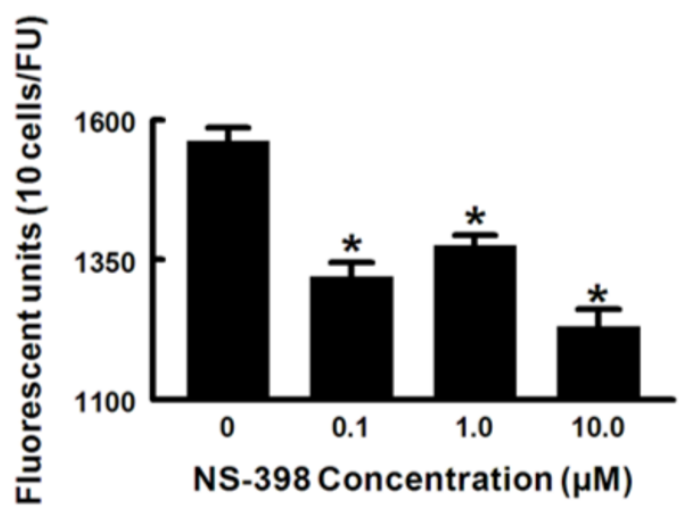

\section{Figure 5}

The effect of NS-398 on invasion of MDA-23I (A) and Hs578T (B) cells. Cells $\left(I \times 10^{5}\right)$ were placed in the upper chamber of the BD BioCoat Tumor Invasion FluoroBlok System with and without NS-398 in serum-free DMEM and allowed to invade for $24 \mathrm{~h}$. FCM was used as a chemoattractant to stimulate the invasion of the cells. Values were significant $\left({ }^{*} \mathrm{p}<0.05,{ }^{* *} \mathrm{p}<0.0 \mathrm{I}\right)$ when compared to untreated controls ( $0 \mu \mathrm{M}$ NS-398).

cancer is only detected when there is an invasive state, then the prognosis is poorer. In fact, $90 \%$ of patients that die of breast carcinoma have bone metastases [26]. COX2 expression may serve as a biomarker that could be assessed to predict the possible progression of the disease. Additionally, understanding the mechanistic and molecular role of COX-2 in tumor progression and the complex multi-step metastatic process can aid in combating breast cancer mortality. In order for metastasis to occur, angiogenesis, cell attachment, dissociation, proteolysis of the matrix and motility are essential steps. Several studies have reported that COX-2 is involved in these complex steps. In this study, we examined the role of COX-2 in breast cancer cell proliferation, invasion and motility in an attempt to improve our understanding of the molecular mechanism of breast cancer metastasis.

Several studies have demonstrated the efficacy of nonselective and selective COX inhibitors on the proliferation of breast cancer cells, using murine cancer models and human cancer cell lines. Harris et al. [27] evaluated the chemopreventive potential of celecoxib and ibuprofen in the DMBA (7, 12-dimethyl-benz [a] anthracene) model of breast cancer in Sprague-Dawley rats. Both drugs significantly reduced tumor incidence, volume and burden. At 40 and $60 \mu \mathrm{M}$, celecoxib suppressed the growth and proliferation in breast cancer cell lines, MDA-231 and MDA435 by inducing apoptosis and cell cycle arrest at the $\mathrm{G}_{0} /$ $\mathrm{G}_{1}$ phase, respectively [28]. Other studies have suggested that high concentrations of COX inhibitors (over $25 \mu \mathrm{M}$ ) promote apoptosis in cancer cells [29-32]. Although we did not detect any effects that may be independent of COX inhibition, other groups have demonstrated that high concentrations of non-selective and selective COX-2 inhibitors may reduce the proliferation or modulate the cell cycle genes in cancer cells independent of COX-2 expression [33-35]. Elder et al. [34] found a dose-dependent anti-proliferative effect of NS-398 in the colorectal cancer cells, S/KS, that does not express detectable levels of COX-2. Both NS-398 and nimesulide induced p21 gene promoter activity in non-small cell lung cancer cells but COX-2 siRNA did not affect the expression of p21 [35]. Based on these prior studies using the selective COX-2 inhibitors, we selected a concentration range of 0.1-100 $\mu \mathrm{M}$ to use in our experimental studies. We found that the lower concentrations significantly affected the breast cancer cells to about the same extent as the higher concentrations [36-38]. The levels that we used are in the achievable range for humans that have been reported for clinically available selective COX-2 inhibitors used as drugs, e.g., celecoxib and meloxicam.

In this study, we demonstrated the anti-proliferative effects of the selective COX-2 inhibitors, NS-398 and NA in the both COX-2 expressing cell lines, MDA-231 and Hs578T. Our findings indicate that these selective inhibitors will only retard the growth of breast cancer cells that express COX-2. The inhibition of Hs578T cell growth reached a plateau around $1.0 \mu \mathrm{M}$ indicating there would be no further decrease at higher concentrations. While a few studies may show that MCF-7 cell growth is inhibited by COX-2 inhibitors [39,40], we found that MCF-7 cancer cells were not affected by the COX-2 inhibitors (data not shown). The inhibition of cancer cell proliferation by COX-2 inhibitors has also been reported for prostate and colon cancer models [41-43]. 
A

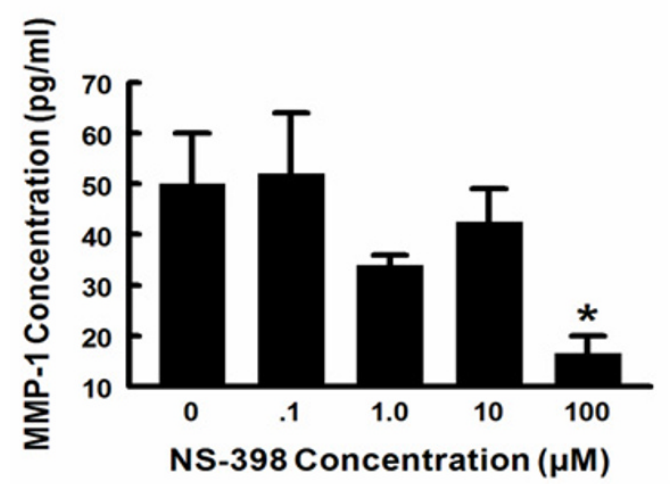

C

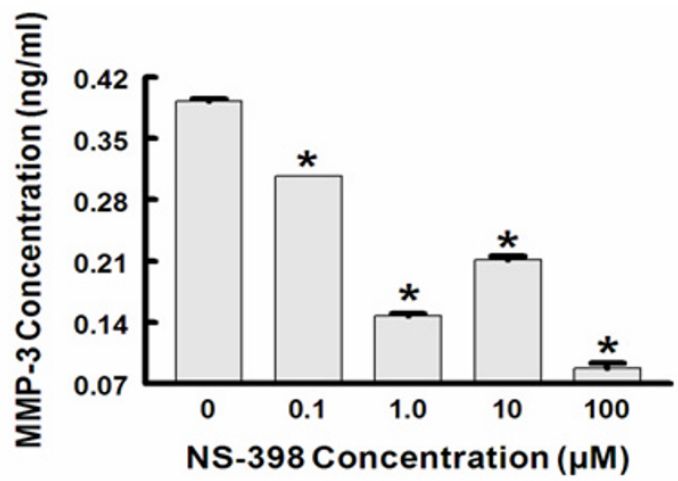

B

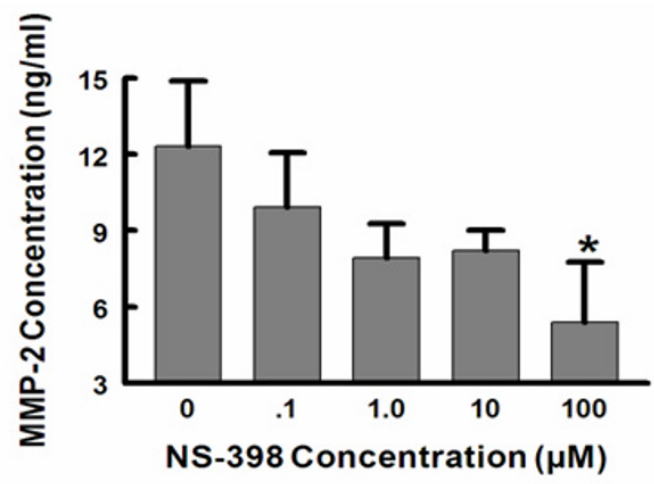

D

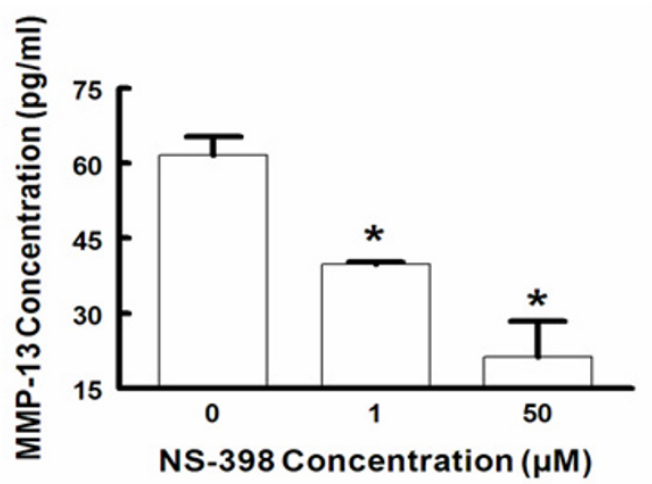

\section{Figure 6}

The effect of NS-398 on metalloproteinase release in culture media by Hs578T cells. The cells were cultured in the presence or absence of increasing doses of NS-398 for $24 \mathrm{~h}$. The levels of the pro and active form of MMPs-I, 2, 3, 9, I0 and I3 were measured in the culture media of treated cells by EIA. A) MMP-I B) MMP-2 C) MMP-3 D) MMP-I3. MMP-9 and MMP-I0 were not detected in Hs578T media. Values were significant ( $\left.{ }^{*} \mathrm{P}<0.05\right)$ when compared to untreated controls $(0 \mu M \mathrm{NS}-398)$.

Cell motility is one of the last critical steps of metastasis which is necessary for a cell to move through the extracellular matrix and enter the circulation where it can travel to a distant site. We were able to demonstrate the inhibitory effect of the selective inhibitors on the motility of the Hs578T and MDA-231 cells. Similarly, Singh et al. [6] showed the addition of $50 \mu \mathrm{M}$ NS-398 inhibited MDA231 cell migration by $47 \%$. Our results also suggest even a lower concentration (i.e. $0.1 \mu \mathrm{M}$ ) of NS-398 causes a decline in the cell motility of the MDA-231 cells. This data confirms that COX-2 activity mediates the chemotaxis of breast cancer cells across a membrane toward a chemoattractant.

With Matrigel, we found that NS-398 partially attenuated the invasive ability of the COX-2-expressing cell lines.
Compared to the control, $10 \mu \mathrm{M}$ NS-398 reduced the invasion of both of the COX-2-expressing cell lines by $10-$ $20 \%$, which is consistent with the findings of Singh et al [6]. These researchers showed that the addition of a higher level of NS-398 (50 $\mu \mathrm{M})$ inhibited MDA-231 invasion through Matrigel by $54 \%$.

In order for the cells to invade and migrate through the basement membrane (i.e., Matrigel), proteolysis of the extracellular matrix must occur. This is accomplished by the secretion and activation of MMPs, which will degrade all extracellular matrix components (e.g., laminin, collagen (all types), entactin and a number of other factors, including growth factors (TGF- $\beta$ and FGF) and cytokines). The association of MMPs with tumor progression is well documented $[7,44,45]$. The expression of MMPs, particu- 


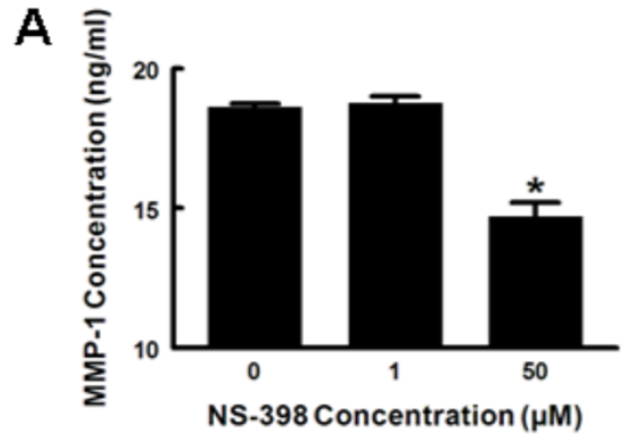

B

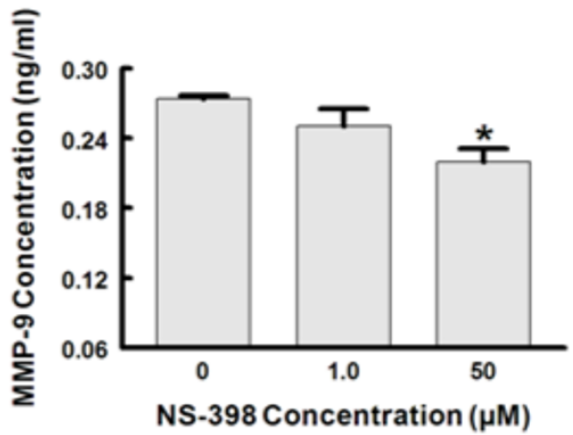

\section{Figure 7}

The effect of NS-398 on metalloproteinase release in culture media by MDA-23 I cells. These cells were cultured in the presence or absence of increasing concentrations of NS-398 for $24 \mathrm{~h}$. The secretion of the pro and active form of MMPs was determined by EIA. A) MMP-I B) MMP-9. MMP-2, MMP3, MMP- 10 and MMP- 3 were not detected in MDA-23 I media. Values were significant $\left({ }^{*} \mathrm{P}<0.05\right)$ when compared to untreated controls (0 $\mu$ M NS-398).

larly the gelatinases (MMP-2 and MMP-9) have been associated with high potential of metastasis in several human carcinomas including breast cancer $[46,47]$. In this study, we also determined the mediation of MMP expression and secretion by COX-2, using an inhibitor approach.

We found a dose-dependent inhibitory effect of NS-398 on the secretion of both pro and active forms of MMPs (1, 2, 3, and 13) in Hs578T cells, which highly express COX2. With $1 \mu \mathrm{M}$ of NS-398 treatment, we found that MMP secretion levels decreased by $50 \%$ or higher. Surprisingly, we did not detect quantifiable levels of the pro and active MMP-9 which has been suggested to be highly expressed by invasive breast carcinomas [48]. We did observe very low MMP-9 mRNA expression in control Hs578T cells, which could account for these results. We were also able to detect an effect of COX-2 inhibition on the expression of MMP mRNAs. NS-398, $1 \mu \mathrm{M}$, decreased MMP mRNA expression to barely detectable levels; there was little change in expression with 10 or $100 \mu \mathrm{M}$ NS-398. This suggest that either there is not dose-dependency or there is a threshold effect of NS-398 on MMP mRNA levels, i.e., a minimum level of COX-2 activity is required to induce the expression of MMP mRNA that we observed in control cells. The $1 \mu \mathrm{M}$ concentration is in the range of the $\mathrm{IC}_{50}$ of NS-398 for the inhibition of COX-2 enzyme activity reported by the manufacturer and by previous studies $[49,50]$, which may account for the drastic decrease it caused in MMP mRNA expression.

Increased levels of various prostaglandins, especially $\mathrm{PGE}_{2}$, have been associated with many different invasive cancers [7,51-53]. Our position is that the ability of NS398 to produce an anti-invasive effect on cancer cell lines is due to the down-regulation of prostaglandin production, which facilitates the functions of COX-2. Our findings also show that COX-2 may exert a tumorigenic effect through $\mathrm{PGE}_{2}$. By inhibiting the COX-2 activity in the Hs578T cells with 1-10 $\mu \mathrm{M}$ NS-398, we were able to reduce the endogenous $\mathrm{PGE}_{2}$ levels by $75 \%$ (unpublished observations). The addition of exogenous $\mathrm{PGE}_{2}$ completely reversed the inhibitory effect of with NS-398 on the expression of all MMP mRNAs by Hs578T cells. In fact, $\mathrm{PGE}_{2}$ treatment of the NS-398 pre-treated Hs578T cells resulted in increased MMP expression, which surpassed basal levels. We also found that NS-398 treatment of MDA-231 also resulted in the inhibition of the pro and active MMPs (1, 2, and 9). Our preliminary studies showed that adding exogenous $\mathrm{PGE}_{2}$ to the control MDA231 cells did not affect or may have decreased the secretion of MMPs. These data suggest that exogenous $\mathrm{PGE}_{2}$, by itself, can not modulate the increase in MMP secretion without a reduction in the endogenous $\mathrm{PGE}_{2}$ levels. Several other studies have also implicated $\mathrm{PGE}_{2}$ in the activation of COX-2 gene expression, which could lead to an increase in active COX-2 and subsequent higher MMP expression [54,55]. Pan et al. [56] showed that NS-398 treatment resulted in a suppression in MMP-2 promoter activity, MMP mRNA and active MMP-2 protein by the A549 lung cancer cell line. Inhibition of the MMP-2 promoter activity by NS-398 was partially reversed by exogenous $\mathrm{PGE}_{2}$. Other studies using a human prostate cancer cell line (DU-145) or a colorectal cancer cell line (MC26), treated with 10 and $100 \mu \mathrm{M}$ NS-398, reported a reduction in the release of pro and active MMP-2 and MMP-9 in the culture media [15,38]. However, the underlying mechanism for how $\mathrm{PGE}_{2}$ up-regulates the expression of MMPs is not known. Further investigations are 
needed to properly explain the phenomenon that we observed in our study.

Contrary to our expectation, we did not see exactly the same MMPs secreted by both of the COX-2-expressing cell lines. We suspect that the difference could be a result of the heterogeneity of the Hs578T cell line or the cell's response to its extracellular environment. The time period used for transcription of the various MMPs in these cells may also explain some of the variability observed. In an in vivo system, the stroma of breast carcinomas may also secrete MMPs in response to high COX-2 expression by the breast tumor, which would also aid in tumor cell invasion. To our knowledge, we are the first to report that the inhibition of COX-2 reduces both MMPs mRNA expression and secretion of pro and active MMPs in breast cancer cell lines where COX-2 is highly expressed. Our study suggests that the MMPs may promote some of the deleterious effects of COX-2, and could possibly be studied as a useful target for combination chemotherapy for breast cancer patients that overexpress COX-2.

\section{Conclusion}

Using an inhibitory approach, we examined the involvement of COX-2 activity promoting breast cancer metastatic behavior. In this report, we confirm that the expression and activity of COX-2 may be a required component for breast cancer cell proliferation, motility and invasion. In our experiments, we showed that treating breast cancer cell lines that express COX-2 with a COX-2 inhibitor decreased proliferation, migration, invasion, and MMP production. Furthermore, we report that $\mathrm{PGE}_{2}$ may mediate the effects COX-2 activity by activating signaling pathways via $\mathrm{PGE}_{2}$ (EP) receptors. However, exogenous $\mathrm{PGE}_{2}$ alone was not able to induce a number of changes seen by exogenous $\mathrm{PGE}_{2}$ when COX-2 was first inhibited. Since currently there is no clear understanding of the mechanism by which COX-2 facilitates the progression of cancer, our studies suggest a strategy for assessing the COX-2 pathway through elucidating possible downstream signaling mediators that have effects on the migration, invasion and expression of MMPs by highly invasive breast cancer cell lines.

\section{Competing interests}

The author(s) declare that they have no competing interests.

\section{Authors' contributions}

TLL implemented the experimental design, carried out the assays and drafted the manuscript. MN participated in performing the cell proliferation studies and the western blotting analysis for MMP protein expression. SS designed and provided the MMP primers, $18 \mathrm{~S}$ primers, $18 \mathrm{~S}$ standard and the set-up for the real-time PCR. GLS aided in the experimental design for the studies, provided the majority of the laboratory materials/equipment and in drafting the manuscript.

\section{Acknowledgements}

This research was supported in part by funds from NASA NCC9-I I2, Georgia Cancer Coalition and NIH grants: RR 03034, GM 08248 and MD 00525. We would like to thank Drs. James Lillard, Ward Kirlin, Gale Newman, Veena Rao and Sandra Harris-Hooker for the use of their resources and scientific advice. Special thanks to other members of the Sanford laboratory- Debra Ellerson, Brandi Brandon and Tammy Wallace for their support and help in this research effort.

\section{References}

I. Parrett ML, Harris RE, Joarder FS, Ross MS, Clausen KP, Robertson FM: Cyclooxygenase-2 gene expression in human breast cancer. Int J Oncol 1997, 10:503-507.

2. Gilhooly EM, Rose DP: The association between a mutated ras gene and cyclooxygenase- 2 expression in human breast cancer cell lines. Int J Oncol 1999, 15:267-270.

3. Liu XH, Rose DP: Differential expression and regulation of cyclooxygenase- $I$ and -2 in two human breast cancer cell lines. Cancer Res 1996, 56:5 I25-5I 27.

4. Ristimaki A, Sivula A, Lundin J, Lundin M, Salminen T, Haglund C, Joensuu $\mathrm{H}$, Isola J: Prognostic significance of elevated cyclooxygenase-2 expression in breast cancer. Cancer Res 2002, 62:632-635.

5. Liu CH, Chang SH, Narko K, Trifan OC, Wu MT, Smith E, Haudenschild C, Lane TF, Hla T: Overexpression of cyclooxygenase-2 is sufficient to induce tumorigenesis in transgenic mice. J Biol Chem 200I, 276: 18563-18569.

6. Singh B, Berry JA, Shoher A, Ramakrishnan V, Lucci A: COX-2 overexpression increases motility and invasion of breast cancer cells. Int J Oncol 2005, 26:1393-1399.

7. Rolland PH, Martin PM, Jacquemier J, Rolland AM, Toga M: Prostaglandin in human breast cancer: Evidence suggesting that an elevated prostaglandin production is a marker of high metastatic potential for neoplastic cells. I Natl Cancer Inst 1980, 64: $1061-1070$.

8. Karmali RA, Welt S, Thaler HT, Lefevre F: Prostaglandins in breast cancer: relationship to disease stage and hormone status. Br J Cancer 1983, 48:689-696.

9. Zhao Y, Agarwal VR, Mendelson CR, Simpson ER: Estrogen biosynthesis proximal to a breast tumor is stimulated by PGE2 via cyclic AMP, leading to activation of promoter II of the CYPI 9 (aromatase) gene. Endocrinology 1996, 137:5739-5742.

10. Dormond O, Foletti A, Paroz C, Ruegg C: NSAIDs inhibit alpha V beta 3 integrin-mediated and Cdc42/Rac-dependent endothelial-cell spreading, migration and angiogenesis. Nat Med 200I, 7:104I-1047.

II. Gately S: The contributions of cyclooxygenase-2 to tumor angiogenesis. Cancer Metastasis Rev 2000, 19:19-27.

12. Takahashi Y, Kawahara F, Noguchi M, Miwa K, Sato H, Seiki M, Inoue $\mathrm{H}$, Tanabe T, Yoshimoto T: Activation of matrix metalloproteinase- 2 in human breast cancer cells overexpressing cyclooxygenase-I or -2. FEBS Lett 1999, 460: I45-I48.

13. Sivula A, Talvensaari-Mattila A, Lundin J, Joensuu $H$, Haglund C, Ristimaki A, Turpeenniemi-Hujanen T: Association of cyclooxygenase- 2 and matrix metalloproteinase-2 expression in human breast cancer. Breast Cancer Res Treat 2005, 89:21 15-220.

14. Guyton DP, Evans DM, Sloan-Stakleff KD: Urokinase Plasminogen Activator Receptor (uPAR): A Potential Indicator of Invasion for In Situ Breast Cancer. Breast J 2000, 6:130-136.

15. Attiga FA, Fernandez PM, Weeraratna AT, Manyak MJ, Patierno SR: Inhibitors of prostaglandin synthesis inhibit human prostate tumor cell invasiveness and reduce the release of matrix metalloproteinases. Cancer Res 2000, 60:4629-4637.

16. Tsujii M, Kawano S, DuBois RN: Cyclooxygenase-2 expression in human colon cancer cells increases metastatic potential. Proc Natl Acad Sci U S A 1997, 94:3336-3340.

17. Dohadwala M, Batra RK, Luo J, Lin Y, Krysan K, Pold M, Sharma S, Dubinett SM: Autocrine/paracrine prostaglandin E2 production by non-small cell lung cancer cells regulates matrix met- 
alloproteinase-2 and CD44 in cyclooxygenase-2-dependent invasion. J Biol Chem 2002, 277:50828-50833.

18. Schreinemachers DM, Everson RB: Aspirin use and lung, colon, and breast cancer incidence in a prospective study. Epidemiology 1994, 5: I38- I 46

19. Harris RE, Namboodiri KK, Farrar WB: Nonsteroidal antiinflammatory drugs and breast cancer. Epidemiology 1996, 7:203-205.

20. Kawamori T, Rao CV, Seibert K, Reddy BS: Chemopreventive activity of celecoxib, a specific cyclooxygenase- 2 inhibitor, against colon carcinogenesis. Cancer Res 1998, 58:409-4I2.

21. Kundu N, Fulton AM: Selective cyclooxygenase (COX)-I or COX-2 inhibitors control metastatic disease in a murine model of breast cancer. Cancer Res 2002, 62:2343-2346.

22. Subbaramaiah K, Zakim D, Weksler BB, Dannenberg AJ: Inhibition of cyclooxygenase: a novel approach to cancer prevention. Proc Soc Exp Biol Med 1997, 21 6:201-210.

23. Norrish AE, Jackson RT, McRae CU: Non-steroidal anti-inflammatory drugs and prostate cancer progression. Int J Cancer 1998, 77:5||-515.

24. Half E, Tang XM, Gwyn K, Sahin A, Wathen K, Sinicrope FA: Cyclooxygenase- 2 expression in human breast cancers and adjacent ductal carcinoma in situ. Cancer Res 2002, 62: |676-|68|.

25. Singh S, Singh UP, Stiles JK, Grizzle WE, Lillard JWJ: Expression and functional role of CCR9 in prostate cancer cell migration and invasion. Clin Cancer Res 2004, 10:8743-8750.

26. Mundy GR, Yoneda T: Facilitation and suppression of bone metastasis. Clin Orthop Relat Res 1995:34-44.

27. Harris RE, Alshafie GA, bou-lssa H, Seibert K: Chemoprevention of breast cancer in rats by celecoxib, a cyclooxygenase 2 inhibitor. Cancer Res 2000, 60:2 101-2103.

28. Basu GD, Pathangey LB, Tinder TL, Gendler SJ, Mukherjee P: Mechanisms underlying the growth inhibitory effects of the cyclooxygenase-2 inhibitor celecoxib in human breast cancer cells. Breast Cancer Res 2005, 7:R422-R435.

29. Gee J, Lee IL, Jendiroba D, Fischer SM, Grossman HB, Sabichi AL: Selective cyclooxygenase-2 inhibitors inhibit growth and induce apoptosis of bladder cancer. Oncol Rep 2006, 15:47|-477.

30. Hiraga T, Myoui A, Choi ME, Yoshikawa H, Yoneda T: Stimulation of cyclooxygenase- 2 expression by bone-derived transforming growth factor-beta enhances bone metastases in breast cancer. Cancer Res 2006, 66:2067-2073.

31. Liu XH, Yao S, Kirschenbaum A, Levine AC: NS398, a selective cyclooxygenase-2 inhibitor, induces apoptosis and down-regulates bcl-2 expression in LNCaP cells. Cancer Res 1998, 58:4245-4249.

32. Mohseni H, Zaslau S, McFadden D, Riggs DR, Jackson BJ, Kandzari S: COX-2 inhibition demonstrates potent anti-proliferative effects on bladder cancer in vitro. J Surg Res 2004, I I 9: I 38- I 42

33. Chan CM, Ma BB, Wong SC, Chan AT: Celecoxib induces dose dependent growth inhibition in nasopharyngeal carcinoma cell lines independent of cyclooxygenase-2 expression. Biomed Pharmacother 2005, 59 Suppl 2:S268-S27I.

34. Elder DJ, Halton DE, Hague A, Paraskeva C: Induction of apoptotic cell death in human colorectal carcinoma cell lines by a cyclooxygenase-2 (COX-2)-selective nonsteroidal antiinflammatory drug: independence from COX-2 protein expression. Clin Cancer Res 1997, 3:1679-I683.

35. Han S, Roman J: COX-2 inhibitors suppress lung cancer cell growth by inducing $\mathrm{p} 2 \mathrm{I}$ via COX-2 independent signals. Lung Cancer 2006, $51: 283-296$

36. Gao XQ, Han JX, Huang HY, Song B, Zhu B, Song CZ: Effect of NS398 on metastasis-associated gene expression in a human colon cancer cell line. World J Gastroenterol 2005, I I:4337-4343.

37. Rozic JG, Chakraborty C, Lala PK: Cyclooxygenase inhibitors retard murine mammary tumor progression by reducing tumor cell migration, invasiveness and angiogenesis. Int J Cancer 200I, 93:497-506.

38. Yao M, Lam EC, Kelly CR, Zhou W, Wolfe MM: Cyclooxygenase2 selective inhibition with NS-398 suppresses proliferation and invasiveness and delays liver metastasis in colorectal cancer. Br J Cancer 2004, 90:7| 2-7/9.

39. Matsumoto G, Rahman MA, Muta M, Nakamura T, Bando H, Saji S, Tsuruta K, Okamoto A, Toi M: DFU, a selective COX-2 inhibi- tor, suppresses MCF-7 xenograft tumor growth in mice. Oncol Rep 2004, I 2:28I-285.

40. Srinath P, Rao PN, Knaus EE, Suresh MR: Effect of cyclooxygenase-2 (COX-2) inhibitors on prostate cancer cell proliferation. Anticancer Res 2003, 23:3923-3928.

4I. Sheng H, Shao J, Kirkland SC, Isakson P, Coffey RJ, Morrow J, Beauchamp RD, DuBois RN: Inhibition of human colon cancer cell growth by selective inhibition of cyclooxygenase-2. J Clin Invest 1997, 99:2254-2259.

42. Yao M, Kargman S, Lam EC, Kelly CR, Zheng Y, Luk P, Kwong E, Evans JF, Wolfe MM: Inhibition of cyclooxygenase-2 by rofecoxib attenuates the growth and metastatic potential of colorectal carcinoma in mice. Cancer Res 2003, 63:586-592.

43. Liu XH, Kirschenbaum A, Yao S, Lee R, Holland JF, Levine AC: Inhibition of cyclooxygenase- 2 suppresses angiogenesis and the growth of prostate cancer in vivo. J Urol 2000, 164:820-825.

44. Chambers AF, Matrisian LM: Changing views of the role of matrix metalloproteinases in metastasis. I Natl Cancer Inst 1997, 89:1260-1270.

45. Duffy MJ, Maguire TM, Hill A, McDermott E, O'Higgins N: Metalloproteinases: role in breast carcinogenesis, invasion and metastasis. Breast Cancer Res 2000, 2:252-257.

46. Barsky SH, Togo S, Garbisa S, Liotta LA: Type IV collagenase immunoreactivity in invasive breast carcinoma. Lancet 1983 , I:296-297.

47. Pacheco MM, Mourao M, Mantovani EB, Nishimoto IN, Brentani MM Expression of gelatinases $A$ and $B$, stromelysin-3 and matrilysin genes in breast carcinomas: clinico-pathological correlations. Clin Exp Metastasis 1998, 16:577-585.

48. Iwata H, Kobayashi S, Iwase H, Masaoka A, Fujimoto N, Okada $Y$ : Production of matrix metalloproteinases and tissue inhibitors of metalloproteinases in human breast carcinomas. Jpn J Cancer Res 1996, 87:602-6II.

49. Futaki N, Takahashi S, Kitagawa T, Yamakawa Y, Tanaka M, Higuchi S: Selective inhibition of cyclooxygenase-2 by NS-398 in endotoxin shock rats in vivo. Inflamm Res 1997, 46:496-502.

50. Ogino K, Hatanaka K, Kawamura M, Katori M, Harada Y: Evaluation of pharmacological profile of meloxicam as an anti-inflammatory agent, with particular reference to its relative selectivity for cyclooxygenase-2 over cyclooxygenase-I. Pharmacology 1997, 55:44-53.

51. Rigas B, Goldman IS, Levine L: Altered eicosanoid levels in human colon cancer. J Lab Clin Med I993, I 22:5 I 8-523.

52. Uefuji $\mathrm{K}$, Ichikura $\mathrm{T}$, Mochizuki H: Cyclooxygenase-2 expression is related to prostaglandin biosynthesis and angiogenesis in human gastric cancer. Clin Cancer Res 2000, 6:135-138.

53. Wang D, DuBois RN: Prostaglandins and cancer. Gut 2005.

54. Tjandrawinata RR, Hughes-Fulford M: Up-regulation of cyclooxygenase-2 by product-prostaglandin E2. Adv Exp Med Biol 1997, 407:163-170.

55. Tjandrawinata RR, Dahiya R, Hughes-Fulford M: Induction of cyclooxygenase- 2 mRNA by prostaglandin E2 in human prostatic carcinoma cells. Br / Cancer 1997, 75: IIII-III8.

56. Pan MR, Chuang LY, Hung WC: Non-steroidal anti-inflammatory drugs inhibit matrix metalloproteinase- 2 expression via repression of transcription in lung cancer cells. FEBS Lett 200I, 508:365-368

\section{Pre-publication history}

The pre-publication history for this paper can be accessed here:

\section{http://www.biomedcentral.com/1471-2407/6/181/pre} pub 